\title{
The Rate of Success of the Accelerated Solvent Extraction (Ase) of Fat and Organochlorine Pesticides from Dried Fish Meat Samples
}

\author{
Ana-Andreea CIOCA $^{1 *}$, Olaf HEEMKEN ${ }^{2}$ and Marian MIHAIU ${ }^{1}$ \\ ${ }^{1 *}$ Department of Animal Production and Food Safety, University of Agricultural Sciences and Veterinary \\ Medicine, 3-5 Mănăștur Street, 400372, Cluj-Napoca, Romania. \\ ${ }^{2}$ Department of Organic Residues,LAVES- Institute for fish and fishery products, Schleusenstraße 1, \\ 27472, Cuxhaven, Germany. \\ *corresponding author: anaandreeacioca@yahoo.com
}

Bulletin UASVM Veterinary Medicine 74(1)/2017

Print ISSN 1843-5270; Electronic ISSN 1843-5378

doi:10.15835/buasvmcn-vm:12589

\begin{abstract}
The replacement of conventional sample preparation techniques with newer techniques which are automated, faster and more eco-friendly, is nowadays desired in every analytical laboratory. One of the techniques with the attributes mentioned above is the Accelerated Solvent Extraction. In order to evaluate how successful this method is for the extraction of fat and organochlorine pesticides (OCPs) from dried fish meat samples, we have tested two series of diverse fish using Dionex ${ }^{\mathrm{TM}} 350$ ASE provided by Thermo Scientific ${ }^{\mathrm{TM}}$ (Germany). For a more interesting approach, we added to our investigation 7 polychlorinated biphenyl (PCBs), 3 thricholorobenzenes, 2 tetrachlorobenzenes, 1 pentachlorobenzenes and 2,3,7,8-tetrachlorodibenzo-p-dioxin (TCDD). The study focused on comparing the recoveries of these analytes from different fish samples, after replacing the conventional reference method of the laboratory with ASE. The ASE parameters tested were previously used for the extraction of fat and polybrominated diphenyl ethers (PBDE) from fish samples: temperature: $120^{\circ} \mathrm{C}$; static time: $5 \mathrm{~min}$; number of cycles: 3; flushing volume: $25 \%$; rinse with nitrogen: 90 s; solvent: cyclohexane/ethyl acetate (ratio 1:1).The ASE method provided similar and in some cases better results when compared to the standard reference method, more rapidly, eco-friendly and safer. Any high or low recoveries of the analytes taken into study are attributed to random or systematic errors during the Clean-up step of the extracts and the quantification with Gas Chromatography coupled with Tandem Mass-Spectrometry (GC MS/MS).
\end{abstract}

Keywords: Accelerated Solvent Extraction, fish meat, organochlorine compounds

\section{INTRODUCTION}

Nowadays an extensive attention is paid by the Food and Agricultural Organization (FAO) and the World Health Organization (WHO) on pesticide residues in food, environment, and the possibility of harm to human following long - term of low levels exposure and consequent effects of chronic poisoning (Arzi et al., 2011). Organochlorine pesticides (OCPs) are characterized by low polarity, low aqueous solubility and high lipid solubility (lipophilicity) and as a result they have potential for bioaccumulation in food chain, posing a great threat to human health and the environment globally (Enbaia et al., 2014). Many OCPs have been implicated in a wide range of adverse human and environmental effects including reproduction, birth defects, immune system dysfunction, endocrine disruption and cancer (Kafilzadeh et al., 2012; Aktar et al., 2009). The aquatic life such as the fish populations, represent an important source 
of food for people (Veljanoska-Sarafiloska et al., 2011) and a way of transfer for these dangerous compounds to superior organisms. Currently, world population generally shows an increasing interest in healthy diets, in which fresh vegetables, fruits and fish has a prominent place for its energy and bio nutritive values. Fish-based diets are associated with climate and tradition; however, the overall consumption of fish is on a steady increase all over the world (Bošnir et al., 2007). In the same time, fish meat and fish fat analysed worldwide, have shown evidence of OCP and PCB enrichment and bioaccumulation(Ibigbami et al., 2015;Therdttepittak et al., 2003; Sethuraman et al., 2013). As the European Food Safety Authority (EFSA) states, from the same category of persistent organic pollutants (POPs), polychlorinated biphenyl (PCBs) and the dioxin group, can cause similar effects with those of OCPsin humans.Their toxicity led to their regulation by the Stockholm Convention 2001 (Oluoch-Otiego et al., 2016) and investigations in this direction are continuously pursued (Petronijevic et al., 2015)

In the last few years, new extraction techniques have been established in order to simplify sample preparation in the process of diverse residue quantifications (De Koning et al., 2009). Such techniques include microwave-assisted extraction (Wang et al., 2010), supercritical fluid extraction and accelerated solvent extraction (ASE) (Heemken et al., 1997). Studies concerning the ASE technique can be also found under the name of pressurized liquid extraction (PLE) such as in the study conducted by Lund et al. (2009); Herranz et al. (2007) etc.

ASE has developed into the most powerful extraction approach in routine analysis of lipids/ fatty acids in biological matrices (Bodin et al., 2009). Furthermore, the relatively new technique has gained considerable interest in analysis conducted in the environmental sector (Bhadekar et al., 2011), with focus on OCPs, PCBs and other chemical substances in simple and complex matrices (Gomes Sant'anna et al., 2012). Great uses indeterminations from water samples (Schäfer et al., 2008),soil samples (Ghani et al., 2007) and food of animal origin (Yu et al., 2012) have been recorded by several authors over the time. Among foods, examples of extractions exist for diverse matrixes such as pork (Zhao et al., 2006), bovine (Draisci et al., 2001), fish (Yarita, 2001), etc. With
ASE, the adverse environmental impact of the conventional reference methods could be reduced in three different ways: reduction of the amount of solvents required; reduction in the amount and the toxicity of solvents and reagents employed in the extraction step, especially by automatization and miniaturization (Stocka et al., 2011). The procedure is highly automated(Kuranchie-Mensah et al., 2013)and it is already especially useful for routine analyses of environmental pollutants and food in many analytical laboratories (GiergielewiczMożajska et al., 2010).It aims to save employee labor and time, while improving the efficiency of the analyte isolation (Cifuentes, 2012) running safe operations without a continuous supervision.

In the present study, we have used an ASE technique that combines elevated temperatures and pressures with liquid solvents (Richter et al., 1996), investigating if it represents a better alternative for the conventional reference method of fat extraction from fish samples. In order to tell if the ASE method is successful, we have conducted a small comparison after the model of Wang et al., 2010 of the recoveries obtained for the analytes of interest (Tab. 1) through the validated reference method of the laboratory and the ASE method.

\section{MATERIALS AND METHODS}

\subsection{SAMPLE COLLECTION}

One set of samples consisted of pike-perch and salmon as part of the official samples brought to the Institute for fish and fishery products, Cuxhaven, Germany. The second set of samples consisted of aquaculture fish from Transylvania region and Oltenia region, Romania. These samples were also used on in a monitoring study of pesticides in aquaculture fish coming from this region. After collection, the fish were slaughtered and transported frozen in clean labelled polyethylene bags to the University of Agricultural Sciences and Veterinary Medicine Cluj-Napoca, Romania. From there, the samples were shipped to the Institute for Fish and Fishery Products Cuxhaven, Germany. The shipping was made in polystyrene insulation boxes containing the frozen samples and dry ice.

\subsection{SAMPLE PREPARATION}

The fishes were left in the refrigerator at $4^{\circ} \mathrm{C}$ one day before the preparation of the samples. After defrost, the fish were washed with cold water and dried with paper towels. The fish from 
Tab. 1 List of analytes of interest

\begin{tabular}{|c|c|c|c|c|c|}
\hline No. & Chemical compound & No. & Chemical compound & No. & Chemical compound \\
\hline 1. & Bromocyclene & 14. & HCB & 27. & PCB 153 \\
\hline 2. & Chlordane, cis- & 15. & $\mathrm{HCH}$, alpha- & 28. & PCB 180 \\
\hline 3. & Chlordane, trans- & 16. & $\mathrm{HCH}$, beta- & 29. & PCB 194 \\
\hline 4. & Chlorpyrifos Methyl & 17. & $\mathrm{HCH}$, delta & 30. & PCB 31 \\
\hline 5. & DDD, o,p- & 18 & $\mathrm{HCH}$, gamma- & 31. & PCB 52 \\
\hline 6. & DDE, p,p- & 19. & Hepachlorepoxid, cis- & 32. & 1,3,5-Trichlorobenzene \\
\hline 7. & DDT, p,p- & 20. & Hepachlorepoxid, trans- & 33. & 1,2,4-Trichlorobenzene \\
\hline 8. & Dieldrin & 21. & Heptachlor & 34. & 1,2,3-Trichlorobenzene \\
\hline 9. & Endosulfan, alpha- & 22. & Octachlostyrol & & $(1,2,3,5+1,2,4,5)$-Tetrachlorobenzene \\
\hline 10. & Endosulfan, beta- & 23. & Oxychlordane & 36. & 1,2,3,4-Tetrachlorobenzene \\
\hline 11. & Endosulfansulfat & & Trifluralin & 37. & Pentachlorobenzene \\
\hline 12. & Endrin & & PCB 101 & 38. & 2,3,7,8-Tetrachlorodibenzo-p-dioxin \\
\hline 13. & Endrine Ketone & 26. & PCB 118 & & \\
\hline
\end{tabular}

each location were cut in fillets. A common sample from each batch (weight ca. $200 \mathrm{~g}$ ) consisting in randomly collected muscle tissue from each fillet, was homogenized in Grindomix GM 200 Retsch (Germany). From each common sample aliquots were freeze-dried in LyoCube 4-8 Alpha 2-4 LSC Martin Christ Freeze Dryers (Germany).

\subsection{CHEMICALS}

Acetone Rotipuran ${ }^{\circledR}$ min. 99,8 \% p.a., n-hexane Rotisolv ${ }^{\circledR}$ min. $99 \%$, Pestilyse, sodium chloride. $\geq 99,5 \%$, p.a and silica gel for column chromatography were purchased from Carl Roth (Germany). Acetone and dichloromethane for residue and pesticide analysis came from AppliChem GmbH (Germany), as well as sodium sulphate anhydrous. Cyclohexane and ethyl acetate came from LAB-SCAN Analytical Sciences (Poland). Helium 5.0 and nitrogen 5.0 came from Linde Gas (Deutschland). Pure certified analytical standards used for external and internal standards came from Sigma-Aldrich (Germany).

\subsection{DETERMINATION OF THE FAT CONTENT USING THE REFERENCE METHOD}

Approximately $1.5 \mathrm{~g}$ of each sample was weighed into a centrifuge tube. $10 \mathrm{ml}$ of acetone were added and the mix was dispersed for $5 \mathrm{~min}$ with an Ultra-Turrax IKA (Germany). Subsequently, the mixture was dispersed with $10 \mathrm{ml}$ of double distilled water and $20 \mathrm{ml}$ of petroleum ether in each case for $5 \mathrm{~min}$. To separate the phases, the sample was centrifuged in a cooling centrifuge at $3000 \mathrm{rpm}, 5$ minutes. The petroleum ether phase was then removed with a pasteur pipette into a $100 \mathrm{ml}$ round-bottomed flask. The empty weight of the flask had been previously determined. In order to obtain a complete extraction of the fat, a dispersion with $20 \mathrm{ml}$ petroleum ether was made for the second time. The organic phase was once again separated. For an extensive phase separation (if an emulsion was present), sodium chloride was added to the sample. The collected organic phases were concentrated on a rotary evaporator for drying. Finally, the round flask was blown off with nitrogen, placed in the drying stove for $1.5 \mathrm{~h}$ at $105^{\circ} \mathrm{C}$, cooled in a desiccator and then weighed. A blank sample was investigated with these samples. The fat content [\%] was calculated from the extracted fat quantity related to the initial weight of the fresh fish sample:

Fat content $[\%]=\frac{(\text { Final weight }- \text { Empty flask }) \times 100}{\text { Initial weight }}$

\subsection{ACCELERATED SOLVENT EXTRACTION}

Approximately $2.0 \mathrm{~g}$ of each freeze-dried sample was transferred into a $24 \mathrm{ml}$ stainless steel ASE extraction cell. The cells were provided with Thermo Scientific ${ }^{\mathrm{TM}}$ stainless steel frits and filters in order to prevent plugging and maximize separation of solvent extract in extraction cells. For interferences retention, the remaining cell volume was filled with sodium sulphate $\left(\mathrm{Na}_{2} \mathrm{SO}_{4}\right)$ 
previously dried at $600^{\circ} \mathrm{C}$ for 6 hours. The packed extraction cell was placed in the Dionex ${ }^{\mathrm{TM}} 350$ ASE provided by Thermo Scientific ${ }^{\mathrm{TM}}$ (Germany). Subsequent extraction conditions were set: temperature: $120^{\circ} \mathrm{C}$; static time: $5 \mathrm{~min}$; number of cycles: 3; flushing volume: $25 \%$; rinse with nitrogen: $90 \mathrm{~s}$; solvent: cyclohexane/ethyl acetate (ratio 1:1).

The ASE sample extract was transferred to a previously weighed $100 \mathrm{ml}$ round-bottomed flask. In order to ensure a complete transfer of the sample, the ASE collection tubes were rinsed 3 times with in each case $2 \mathrm{ml} \mathrm{n}$-hexane. The extract was then concentrated at $40^{\circ} \mathrm{C}$, in a rotary evaporator provided by BUCHI (Germany). After this step, the sample was blown off with nitrogen and then weighed on the analytical balance provided by Sartorius (Germany). Until the weight constancy was adjusted, the sample was blown off with nitrogen. A blank sample consisting in approx. 10 g sodium sulphate $\left(\mathrm{Na}_{2} \mathrm{SO}_{4}\right)$ and water $\left(\mathrm{H}_{2} \mathrm{O}\right)$ was analysed with the samples. The fat content was calculated according to the formula mentioned at 2.4. One ml purified extracts are transferred into vials and measured on GC-MS/ MS which came from Agilent Technologies (USA). The oven of the instrument was set to $0.5 \mathrm{~min}$ equilibration time, $325^{\circ} \mathrm{C}$ maximum temperature, slow fan disabled, oven program on at $70^{\circ} \mathrm{C}$ for 2 min, then $25^{\circ} \mathrm{C} / \min$ to $150^{\circ} \mathrm{C}$ for $0 \mathrm{~min}$, then $3{ }^{\circ} \mathrm{C} /$ $\min$ to $200{ }^{\circ} \mathrm{C}$ for $0 \mathrm{~min}$, then $8{ }^{\circ} \mathrm{C} / \mathrm{min}$ to $280{ }^{\circ} \mathrm{C}$ for $10 \mathrm{~min}$ and $41.867 \mathrm{~min}$ run time. The injector temperature was $280^{\circ} \mathrm{C}$ and $10 \mu \mathrm{L}$ was injected with 2 injection repetitions of $5 \mu \mathrm{L}$ volume. Helium was used as a quench gas with $2.25 \mathrm{~mL} /$ min and nitrogen as collision gas with $1.5 \mathrm{~mL} / \mathrm{min}$. Front PTV inlet He was operated in PTV solvent vent mode, with heater on $60^{\circ}$, pressure 14.091 psi, total flow $34.5 \mathrm{~mL} / \mathrm{min}$, septum purge flow3 $\mathrm{mL} / \mathrm{min}$, program temperature $60{ }^{\circ} \mathrm{C}$ for $0.2 \mathrm{~min}$, then $650{ }^{\circ} \mathrm{C} / \mathrm{min}$ to $285^{\circ} \mathrm{C}$ for $0 \mathrm{~min}$. The column used was Agilent 19091S-433: 1405.62937 HP5MS 5\% Phenyl Methyl Silox325 ${ }^{\circ} \mathrm{C}: 30 \mathrm{~m}$ x 250 $\mu \mathrm{m} \times 0.25 \mu \mathrm{m}$. Samples were analysed in triplicate. The concentrations were read in MS Quantitative Analysis software provided with the instrument.

\section{RESULTS AND DISCUSSIONS}

All ASE recoveries [\%] were calculated from the final concentration and native concentration in relation with the spiked level as following:
$[\%]$ Recovery $=\frac{(\mathrm{Fc}-\mathrm{Fn}) \times 100}{50}$

Where $\mathrm{F}_{\mathrm{c}}$ - final concentration

$\mathrm{F}_{\mathrm{n}-\mathrm{s}}$ native concentration

50- spike level

A mean value and the corresponding standard deviation were calculated for each compound and interpreted.

\subsection{COMPARISON OF THE RESULTS FROM PIKE-PERCH AND SALMON SAMPLES}

All of the following interpretations of the results are linked to Fig. 1. Regarding the chlorobenzene group consisting in 1,3,5-trichlorobenzene, 1,2,4-trichlorobenzene, 1,2,3-trichlorobenzene, $\quad(1,2,3,5+1,2,4,5)$-tetracholorobenzene, 1,2,3,4,5-tetrachlorobenzene and 1,2,3,4,5-tetrachlorobenzene, the mean recoveries obtained for the different types of samples were mostly not reliable. These compounds are highly volatile and can be easily lost especially during the evaporation process. Compounds such as the thricholorobenzene group showed low to undetectable concentrations. Better recoveries were recorded for the tetrachlorobenzene group in a range of $95-107 \%$ in the salmon samples, but only $31-45 \%$ in pike-perch samples. Within this group, pentachlorobenzene was the only compound recovered in a very good proportion. The results point to a recovery of the analyte in a range of 89-110 $\%$ in both samples. the only compound recovered in a range of $89-110 \%$ in both samples. This may be attributed to a better stability of the analyte, given by the chemical and physical proprieties. For OCs and PCBs, the recoveries obtained were in a range of 86-106 \% in pike-perch and 82-101 $\%$ in salmon samples. Sometimes high recoveries obtained were like in in the case of $\mathrm{HCH}$-alpha, chlorpyrifos methyl, endosulfansulfat and DDT p,p can be caused by systematic errors, accumulations in the GC-MS/MS column or sample contamination during preparation. Low recoveries as in the case of octachlostyrol, hepachlorepoxid cis and oxichlordane, can orientate us towards improving chromatographic conditions for these compounds. An $80-82 \%$ recovery of TCDD is a promising result for the determination of dioxins with this method and along with other compounds mentioned above. 


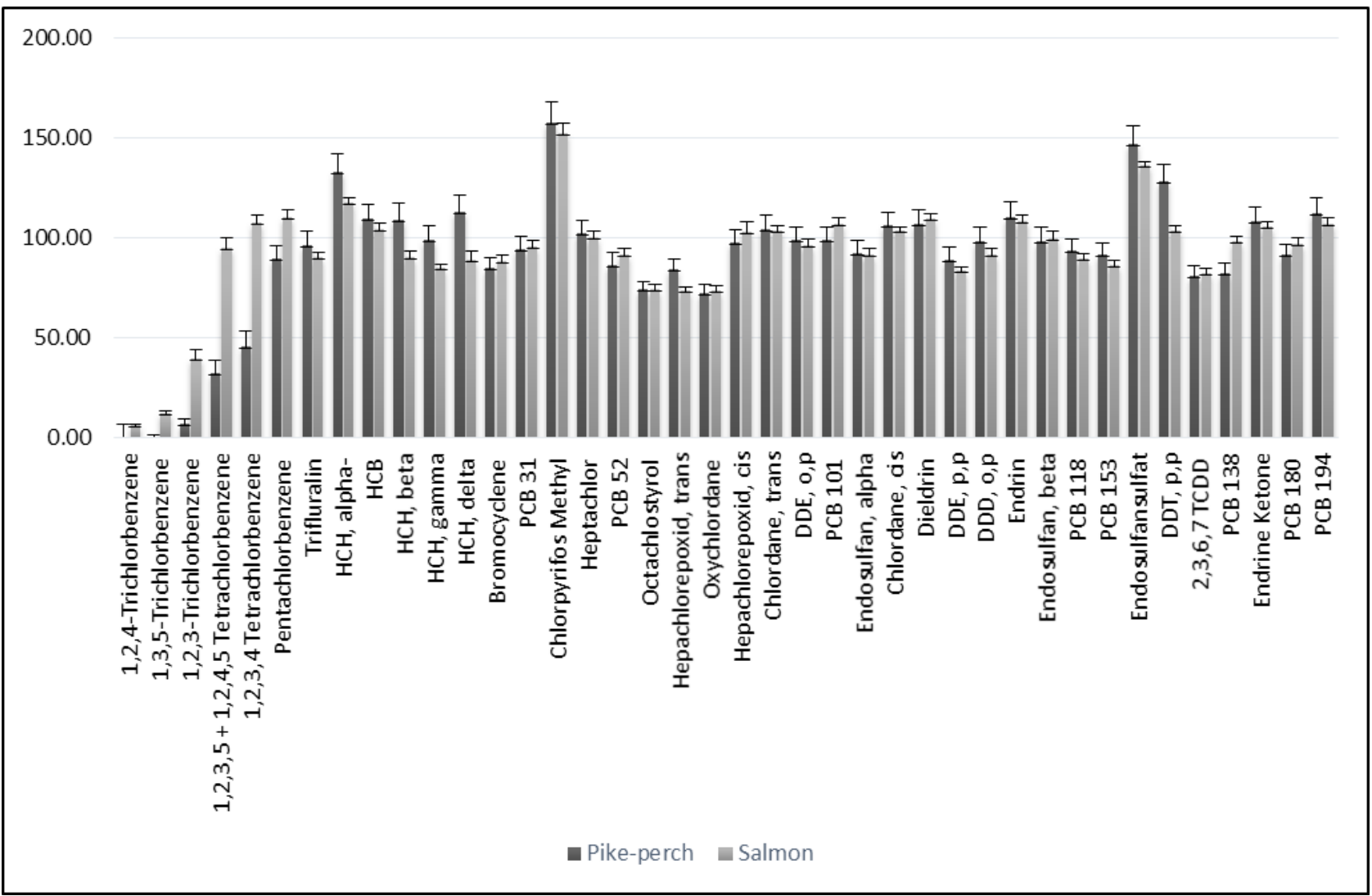

Fig. 1 [\%] recoveries after ASE extraction of OCs, PCBs, chlorobenzene compounds and TCDD from pike-perch and salmon samples.

\subsection{COMPARISON OF THE RESULTS FROM RAINBOW TROUT AND CARP SAMPLES}

\subsubsection{Comparison of fat content recoveries} using reference method and ase method

For a more detailed look upon the quality of the automated method, we have compared the fat content [\%] of 12 fish samples with different fat contents using in parallel the reference method and the ASE method (Tab. 2). The fat contents [\%] obtained with the ASE method were very close to the ones obtained with the reference method for 9 out of 12 fish samples taken into comparison. These samples had a recovery rate in the range of $88,59-103,62 \%$. For the other 3 samples, the recovery rates [\%] were in a range of $76,75-88,59$ $\%$. An analytical error during the extraction with the reference method is considered for sample no 3. The average mean of the fat content using the reference method was calculated from a 2 samples, one having the fat content of 7,30 \% and a replicate with $9,65 \%$. This difference indicated a possible error due to user intervention. This cannot be excluded in the case of a conventional reference method. In the same time, an unexpected power drop with the interruption of the ASE method, resulted in a 76,75\% recovery rate for sample no 7. In this case, the average mean of the fat content with the ASE method, was calculated from a sample having the fat content of $4,45 \%$ and a replicate with 7,89\%.Recovery rates of the ASE method below $100 \%$ can appear due to incomplete extractions of the matrix or of the fat from the samples. An optimization of the process is to be considered.

To clarify whether the extraction efficiency is influenced by the fat content of the sample, a correlation was performed (Fig. 2). The result showed that there is no linear relationship between the fat content of the samples and the recovery rates of the ASE method. 
Tab. 2.The fat content [\%] from rainbow trout $(n=9)$ and carp $(n=3)$ using the reference method and the ASE method. The recovery rates of the ASE method [\%] calculated from the fat content ASE [\%] in correlation with the fat content reference method [\%].

\begin{tabular}{lccc}
\hline \multicolumn{1}{c}{ Sample } & $\begin{array}{c}\text { Fat content reference } \\
\text { method[\%] }\end{array}$ & $\begin{array}{c}\text { Fat content ASE } \\
\text { method [\%] }\end{array}$ & $\begin{array}{c}\text { Recovery rates ASE } \\
\text { method [\%] }\end{array}$ \\
\hline 1. Rainbow trout & 3,74 & 3,54 & 94,84 \\
\hline 2. Rainbow trout & 4,14 & 4,29 & 103,62 \\
\hline 3. Rainbow trout & 8,48 & 7,23 & 85,32 \\
\hline 4. Rainbow trout & 6,06 & 5,53 & 91,23 \\
\hline 5. Rainbow trout & 5,09 & 5,09 & 100,03 \\
\hline 6. Rainbow trout & 3,14 & 2,92 & 92,84 \\
\hline 7. Rainbow trout & 8,04 & 6,17 & 76,75 \\
\hline 8. Rainbow trout & 3,30 & 2,93 & 88,59 \\
\hline 9. Rainbow trout & 4,60 & 4,39 & 95,39 \\
\hline 10. Carp & 4,49 & 4,319 & 96,17 \\
\hline 11. Carp & 4,67 & 4,64 & 99,31 \\
\hline 12. Carp & 7,312 & 7,188 & 98,30 \\
\hline
\end{tabular}

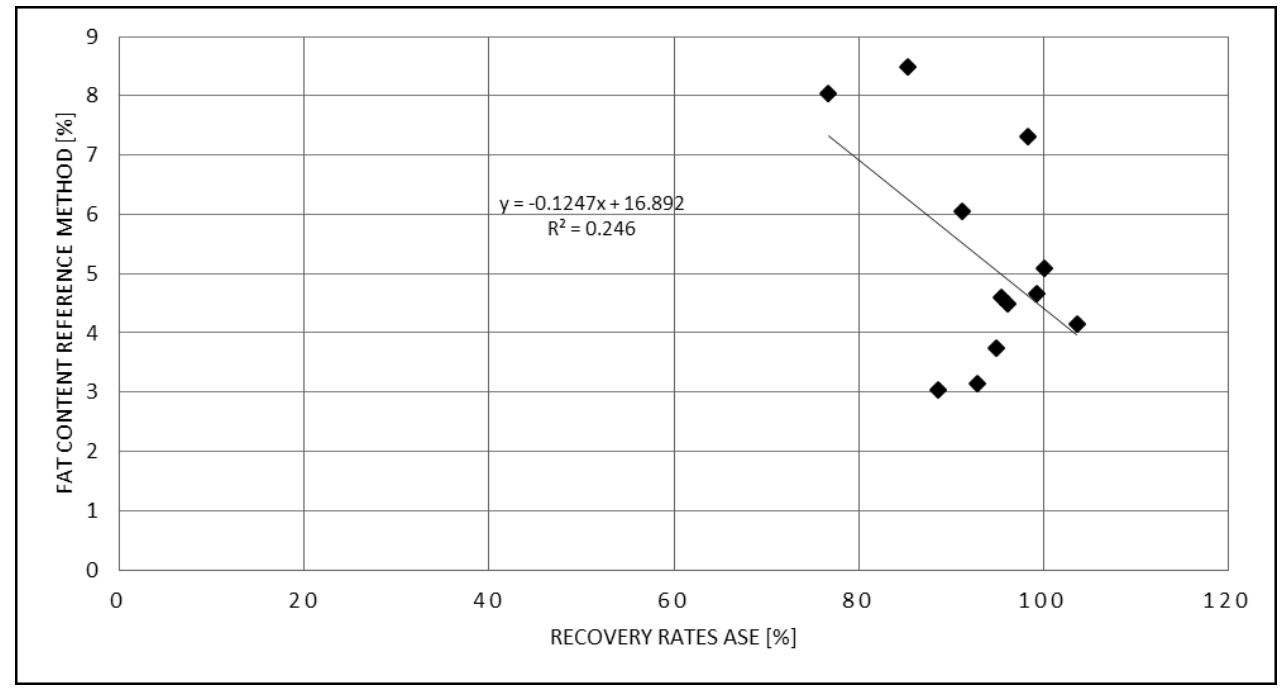

Fig. 2 Correlation of the fat content [\%] determined withthe reference method and the recovery rates of the ASE [\%].

3.2.2 Comparison of the results from rainbow trout and carp samples

All of the following result interpretations refer to Fig. 3. With improved chromatographic conditions and meticulous handling during the evaporation process, a better recovery of the chlorobenzene group was obtained. In this case the recoveries of the tetracholorobenzene group and pentachlorobenzene were in the close nearby of $100 \%$, with small fluctuations which can be normalized by applying correction factors. Low recoveries remain constant for the thricholorobenzene group as previously observed in pike-perch and salmon samples. A high recovery value and standard deviation of DDE, $\mathrm{p}$ are attributed to random errors in this case. A controversial result was given by $\mathrm{HCH}$ isomers, beta and delta. In trout samples the recoveries only reached $31-32 \%$ and in carp samples $48-50$ $\%$. More investigation will be conducted in order 


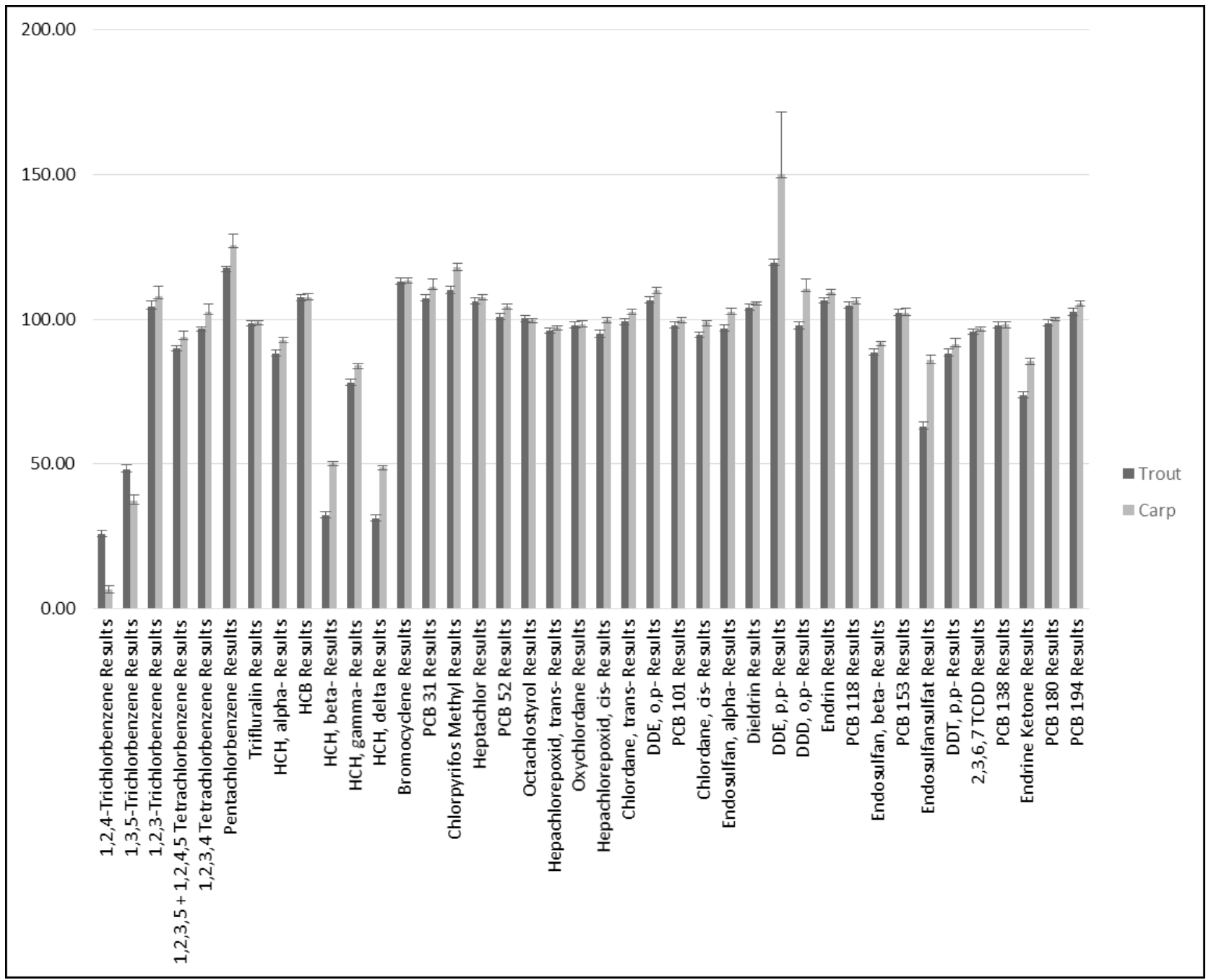

Fig. 3 Recoveries in percentage after ASE extraction of OCs, PCBs, chlorobenzene compounds and TCDD from trout and carp samples.

to obtain the appropriate conditions for these compounds. TCDD was recovered in both trout and carp samples with a value of $95 \%$, respectively $96 \%$.

\section{CONCLUSIONS}

In summary, the ASE technique previously used for the extraction of fat with PDBEs in fish samples was successful for the extraction of fat with OCs, PCBs from different species of fish. More investigations have to be done in order to be able to quantify chlorobenzenes with this means or other methods must be chosen for this group of substances. The technique and the overall method is efficient for the quantification of TCDD. The method provides comparable or even better results than the conventional reference method, with fat recoveries ranging from 76-103\%. Any high or low recoveries of the analytes of interest are therefore attributed to random or systematic errors in the Clean-up step of the extracts or in the quantification step using GC MS/MS. A replacement of the reference method is considered, as ASE is reducing extraction time, is automated, safer and more eco-friendly.

Acknowledgements. We gratefully acknowledge the financial support from the German Federal Environment Foundation (DBU Osnabrück). 


\section{REFERENCES}

1. Aktar MW, Sengupta D, Chowdhury A (2009). Impact of pesticides use in agriculture: their benefits and hazards. Interdiscip Toxicol. 2(1): 1-12.

2. Arzi A, Hemmati AA, Khorasgani ZN (2011). Determination and Comparison of the Organochlorine Pesticide Residue Levels Among Benni Fish of Shadegan, Mahshahr And Susangerd Cities, Khozestan Province In Iran, Jundishapur Journal of Natural Pharmaceutical Products 6(1): 24-31.

3. Bhadekar R, Pote S, Tale V, Nirichan B (2011). Developments in Analytical Methods for Detection of Pesticides in Environmental Samples. American Journal of Analytical Chemistry 2, 1-15.

4. Bodin N, Budzinski H, Le Ménach K, Tapie N (2009). ASE extraction method for simultaneous carbon and nitrogen stable isotope analysis in soft tissues of aquatic organisms, Analytica Chimica Acta 643: 54-60.

5. Bosnir J, Puntaric D, Smit Z, Klaric M, Grgic M, Kosanovic LM (2007). Organochlorine Pesticides in Freshwater Fish from the Zagreb Area, Arh Hig Rada Toksikol 58:187-193.

6. Ghani NM, Saim N, Osman R, Munir ZA (2007). Accelerated Solvent Extraction Method with One-Step Clean-up for Hydrocarbons in Soil, The Malaysian Journal of Analytical Sciences, 11 1: 193-197.

7. Cifuentes A, (2012), Food Analysis: Present, Future, and Foodomics. Analytical Chemistry Volume 2012, Article ID 801607, 16 pages.

8. De Koning S, Janssen HG, Brinkman UT (2009). Modern Methods of Sample Preparation for GC Analysis, Chromatographia 69, S33-S78.

9. Draisci R, Marchiafava C, Palleschi L, Cammarata P, Cavalli $S$ (2001). Accelerated solvent extraction and liquid chromatography-tandem mass spectrometry quantitation of corticosteroid residues in bovine liver, Journal of Chromatography B 753(2):217-23.

10. Enbaia S., Ahmad M., Abusrwil A., Omar A.A., Amra H.A. (2014), Determination of organochlorine pesticide residues in Libyan fish, Int. Journal Curr. Microbiology App.Sci 3(10) 198-212.

11. Giergielewicz-Możajska H, Dąbrowski $\quad$, Namieśnik J (2010). Accelerated Solvent Extraction (ASE) in the Analysis of Environmental Solid Samples- Some Aspects of Theory and Practice, Journal Analytical Chemistry 31 3:149-165.

12. Gomes Sant'anna S, Rodrigues Oliveira CD, De Albuquerque Diniz EM, Yonamine M (2012). Accelerated Solvent Extraction for Gas Chromatographic Analysis of Nicotine and Cotinine in Meconium Samples, Journal of Analytical Toxicology Volume 36, Issue 1Pp. 19-24.

13. Heemken O, Theobald N, Wenclawiak BW (1997) Comparison of ASE and SFE with Soxhlet, Sonication, and Methanolic Saponification Extractions for the Determination of Organic Micropollutants in Marine Particulate Matter, Anal. Chem. 69, 2171-2180.

14. Herranz S, Moreno-Bondi MC, Marazuelam MD (2007). Development of a new sample pretreatment procedure based on pressurized liquid extraction for the determination of fluoroquinolone residues in table eggs, Journal of Chromatography A, 1140: 63-70.

15. Ibigbami OA, Aiyesanmi AF, Adeyeye EI, Adebayo AO (2015). Persistent Organochlorine Pesticide Residues in Water, Sediments and Fish Samples from Ogbese River, Environment and Natural Resources Research; Vol. 5, No. 3

16. Kafilzadeh F, Shiva AH, Malekpour R, Azad HN (2012). Determination of Organochlorine Pesticide Residues in Water, Sediments and Fish from Lake Parishan, Iran, World Journal of Fish and Marine Sciences 4 (2): 150-1.

17. Kuranchie-Mensah H, Yeboah PO, Nyarko E, Golow AA (2013). Studies on Organochlorine Pesticide Residue in Fishes from the Densu River Basin, Ghana. Bulletin of Environmental Contamination and Toxicology $904421-$ 426.

18. Lund M, Duedahl-Olesen L, Christensen JH (2009). Extraction of polycyclic aromatic hydocarbons from smoked fish using pressurized liquid extraction with integrated fat removal, Talanta 79:10-15

19. Oluoch-Otiego J, Oyoo-Okoth E, Kiptoo KK, Chemoiwa EJ, Ngugi CC, Simiyu G, Omutange ES, Ngure V, Opiyo MA (2016). PCBs in fish and their cestode parasites in Lake Victoria, Environ Monit Assess 188(8):483.

20. Petronijevic R, Radicevic T, Jankovic V (2015). Methods for Determination of Dioxins and Dioxin-like Compounds - A Brief Review of Recent Advances, Procedia Food Science 5 227-230.

21. Richter BE, Jones BA, Ezzell JL, Porter NL (1996). Accelerated Solvent Extraction: a Technique for Sample Preparation, Analytical Chemistry (68):6.

22. Schäfer R. B., Mueller R., Brack W., Wenzel K-D., Streck G., Ruck W.,Liess M., (2008), Determination of 10 particleassociated multiclass polar and semi-polar pesticides from small streams using accelerated solvent extraction. Chemosphere 70 1952-1960.

23. Sethuraman A, Kiros S, Tomass Z (2013). Residues of Organochlorine Pesticides in Fishes from the Mumbai West Coast of India. Int. J. Pure Appl. Zool., 1(1): 109-116.

24. Stocka J, Tankiewicz M, Biziuk M, Namieśnik J (2011). Green Aspects of Techniques for the Determination of Currently Used Pesticides in Environmental Samples, Int J Mol Sci. 12(11): 7785-7805.

25. Therdttepittak A, Yammeng K (2003). Determination of Organochlorine Pesticides in Commercial Fish by Gas Chromatography with Electron Capture Detector and Confirmation by Gas-Chromatography with MassSpectrometry, Science Asia 29:127-134.

26. Yarita T (2001). Extraction Behaviour of Accelerated Solvent Extraction of DDT Metabolite from Fish Matrix, Analytical Sciences 17 Supplement 1913.

27. Yu H, Tao Y, Chen D, Pan Y, Liu Z, Wang Y, Huang L, Dai M, Peng D, Wang X, Yuan Z (2012). Simultaneous determination of fluoroquinolones in foods of animal origin by a high performance liquid chromatography and a liquid chromatography tandem mass spectrometry with accelerated solvent extraction, Journal of Chromatography B 885-886 150-159. 
28. Veljanoska-Sarafiloska E, Jordanoski M, Stafilov T, Stefova M (2011). Study of Organochlorine Pesticide Residues in Water, Sediment and Fish Tissue in Lake Ohrid (Macedonia/Albania), Macedonian Journal of Chemistry and Chemical Engineering, Vol. 30, No. 2, pp. 163-179.

29. Wang P, Zhang Q, Wang Y, Wang T, Li X, Ding L, Jiang G (2010). Evaluation of Soxhlet extraction, accelerated solvent extraction and microwave-assisted extraction for the determination of polychlorinated biphenyls and polybrominated diphenyl ethers in soil and fish samples, Analytica Chimica Acta 663(1):43-8.

30. Zhao H, Wang L, Qiu Y, Zhou Z, Li X, Zhong W (2006). Simultaneous determination of three residual barbiturates in pork using accelerated solvent extraction and gas chromatography-mass spectrometry, Journal of Chromatography B, 840 139-145. 